7. Reprod. Fert. (1974) 40, 291-303

\title{
MACROMOLECULAR COMPONENTS OF THE LUMINAL FLUID FROM THE BOVINE UTERUS
}

\author{
G. P. ROBERTS* AND J. M. PARKER \\ Agricultural Research Council, Institute for Research on Animal Diseases, \\ Compton, Newbury, Berkshire
}

(Received 24th September 1973)

\begin{abstract}
Summary. The macromolecular components of the luminal fluid from the uterine horns of 135 cows at different stages of the oestrous cycle or early pregnancy were examined by polyacrylamide gel electrophoresis at $\mathrm{pH} 4.5$ and $\mathrm{pH} 8.9$, isoelectric focusing on polyacrylamide, immunoelectrophoresis and gel filtration. The components present were mainly serum proteins but small amounts of uterine-specific proteins were detected by disc electrophoresis at $\mathrm{pH} 4.5$. The mobility and amounts of these proteins varied according to the reproductive state.

The possible significance of these uterine-specific proteins on embryonic development and control of luteolysis is discussed.
\end{abstract}

\section{INTRODUGTION}

While there exist several reports on the gross chemical composition of the uterine secretions of a number of animals (cow: Olds \& VanDemark, 1957; sheep: Iritani, Gomes \& VanDemark, 1969), it is chiefly in the rabbit that any extensive characterization of the macromolecular constituents of the uterine fluid has been undertaken. To some extent this is due to the fact that the uterine secretion of the rabbit is unusual in its composition. The macromolecular constituents of rabbit uterine fluid were first investigated by Schwick (1965). Of the readily identifiable and specific components found during early pregnancy, one, named blastokinin or uteroglobulin, has been isolated and chemically characterized (Krishnan \& Daniel, 1967, 1968; Beier, 1968; Murray, McGaughey \& Yarus, 1972; McGaughey \& Murray, 1972) and three others were investigated by Kirchner (1969a, b). In other species, however, such as the rat, mink, dog, armadillo, black bear, fur seal, ruminants and man, the situation is less clear for although specific proteins have been identified, they are not present in amounts comparable to that of blastokinin in the rabbit (Daniel, 1968, 1971; Bernstein, Aladjem \& Chen, 1971; Shirai, Iizuka \& Notake, 1972).

Cows are useful models to study the effect of uterine secretions on embryonic development in early pregnancy since the embryo lies free in the uterine space for a relatively long time and implantation does not take place until considerable growth and development of the embryo has taken place. In addition, the econo-

\footnotetext{
* Present address: Department of Surgery, Welsh National School of Medicine, Cardiff GF4 4XN.
} 
mic importance of these animals ensures that disorders of reproduction are detected in normal animal husbandry and a steady supply of animals is available for the correlation of uterine factors with infertility. We report here the results of investigations on the components of the uterine fluid from the cow in early pregnancy obtained by rinsing the uteri after slaughter.

\section{Animals}

\section{MATERIALS AND METHODS}

A total of 135 mature multiparous cows were observed for behavioural oestrus and 114 of these were mated. After the appropriate experimental period, the animals were slaughtered conventionally with a captive-bolt pistol and the genital tract was excised as rapidly as possible, usually within 2 to 3 min of death. The ovaries were examined and the uterus clamped above the cervix. The genital tract was freed of connective tissue, the oviducts were removed and the uterus was bisected by cutting between the horns, care being taken to cover the exposed muscular tissue with a paper towel. Each horn was then washed successively from the cranial end with $4 \times 5 \mathrm{ml}$ normal saline followed by $3 \times 5 \mathrm{ml} 0.05 \mathrm{~m}$-bicarbonate buffer, $\mathrm{pH} 8.0$, containing $0.1 \mathrm{M}-\mathrm{N}$ acetylcysteine and $0.1 \mathrm{M}$-sodium chloride. The first $5 \mathrm{ml} \mathrm{N}$-acetylcysteine solution was allowed to remain in contact with uterine horn for 10 min before draining. Each horn was then cut open and the endometrial layer was scraped gently with a glass slide.

The washings were centrifuged to remove débris and when the fetus was not obvious (i.e. when mating to slaughter times were less than about 14 days), the sediment from the first saline wash was microscopically examined for the embryo, which was usually found. With mating to slaughter times greater than about 25 days, the fetus and associated membranes were separated and the allantoic fluid was aspirated. After removing insoluble matter, the saline rinsings were pooled, dialysed to zero ionic strength and freeze dried. The three Nacetylcysteine washings were also pooled and treated similarly. In general, there was little difference between the material isolated from these two irrigation fluids.

Uterine washings were obtained from six rabbits by a similar procedure.

\section{Gel electrophoresis}

This was performed as described by Davis (1964) and Akroyd (1967), using conditions under which migration to the anode $(\mathrm{pH} \mathrm{8.9)}$ and to the cathode ( $\mathrm{pH} 4.5$ ) occurred (Reisfeld, Lewis \& Williams, 1962). Generally, sample gels were not employed, the uterine proteins being dissolved in $20 \mu \mathrm{l}$ of $20 \%$ sucrose and placed directly on the running gel containing $7.2 \%$ total concentration, $\mathrm{T}$, of the monomers and $2.56 \%$ of $\mathrm{C}$, the cross-linking compound, $\mathrm{NN}^{\prime}$ methylenebis (acrylamide). Bromophenol blue and methyl green respectively were used as marker dyes for the $\mathrm{pH} 8.9$ and $\mathrm{pH} 4.5$ conditions. After completion of the electrophoresis, the proteins were stained with $1 \%$ naphthalene black 12B (BDH Chemicals Ltd., Poole, Dorset) in 7\% acetic acid and glycoproteins were stained using the periodic acid-Schiff (PAS) staining procedure described by Zacharius, Zell, Morrison \& Woodlock (1969). 
Isoelectric focusing on polyacrylamide gels

This was carried out as described by Awdeh, Williamson \& Askonas (1968). The position of the protein bands was identified with Coomassie Brilliant Blue (Vesterberg, 1971).

\section{Gel filtration}

Gel filtration was carried out at $4^{\circ} \mathrm{C}$ on columns of Sephadex G-200 $(1.5 \mathrm{~cm} \times$ $85.0 \mathrm{~cm})$ or Sephadex G-25 Fine $(1.6 \mathrm{~cm} \times 84 \mathrm{~cm})$, elution being performed with a buffer made by adjusting $0.02 \mathrm{M}$-disodium hydrogen phosphate to $\mathrm{pH} 7.4$ with $0.01 \mathrm{M}$-citric acid and containing $0.02 \%$ sodium azide. Fractionation of uterine proteins on a column of Sephadex G-100 $(0.6 \mathrm{~cm} \times 50 \mathrm{~cm})$ was carried out using $0 \cdot 1$ m-pyridine acetate buffer, $\mathrm{pH} 4 \cdot 0$, for elution.

\section{Immunochemical methods}

Samples $(1 \mathrm{mg})$ of the freeze-dried saline washes of the uteri from four cows at oestrus and twenty-eight cows at various stages of pregnancy up to 35 days were combined and a $1 \%$ solution in normal saline was prepared.

Antisera to the uterine proteins and to bovine serum were prepared in rabbits by emulsifying $1 \mathrm{ml}$ of the $1 \%$ solution of uterine proteins or $2.5 \mathrm{ml}$ serum with equal volumes of Freund's complete adjuvant (Difco Laboratories, East Molesey, Surrey) and injecting the mixtures intramuscularly into each of the hind legs. After 2 weeks, a further $1 \mathrm{ml}$ uterine protein solution or $2.5 \mathrm{ml}$ serum emulsified with an equal amount of Freund's incomplete adjuvant (Difco Laboratories) was injected intramuscularly into the rabbit's hind legs. The rabbits were injected intraperitoneally with $0.2 \mathrm{ml}$ of $1 \%$ uterine proteins or $0.5 \mathrm{mI}$ serum after a further 2 weeks followed the next day by an intravenous injection of $0.1 \mathrm{ml}$ of $1 \%$ uterine protein or $0.2 \mathrm{ml}$ serum. The rabbits were bled from the marginal ear vein 5 days after the last intravenous injection. The intraperitoneal and intravenous injection sequence was repeated at monthly intervals until a satisfactory antiserum was produced. Double diffusion in agar was used to test the antisera for precipitins according to the method of Ouchterlony (1958).

Immunoelectrophoresis was carried out by the method of Scheidegger (1955) and also by first separating the proteins by disc electrophoresis (Davis, 1964) on rods of polyacrylamide gel followed by splitting the rods lengthwise, staining one half for proteins and placing the other half in a well cut in a plate of $1.5 \%$ agar gel in $0.05 \mathrm{M}$-phosphate buffer, $\mathrm{pH} 8.0$, containing $0.15 \mathrm{M}$-sodium chloride, $0.01 \mathrm{~m}$-sodium azide and 0.0035 m-EDTA. The agar gel contained an antiserum well cut parallel to the well containing the acrylamide gel and at a distance of $0.6 \mathrm{~cm}$ away from it. Diffusion was allowed to proceed for 2 to 3 days in a moist atmosphere.

Crossed immunoelectrophoresis was carried out on slide cover glasses $(5 \mathrm{~cm} \times$ $5 \mathrm{~cm}$ ) as described by Davies, Spurr \& Versey (1971).

\section{Pronase digestion}

The dialysed and freeze-dried uterine scrapings ( $30 \mathrm{mg}$ ) were suspended in

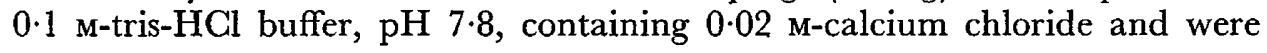


treated with $10 \%$ by weight of Pronase $(45,000$ PUK units--BDH Chemicals $\mathrm{Ltd})$ at $37^{\circ} \mathrm{C}$ in the presence of toluene for $24 \mathrm{hr}$. The material was mostly solubilized by this treatment but there was a small amount of insoluble material remaining after $24 \mathrm{hr}$. This was removed by centrifugation and the supernatant was either dialysed or submitted to fractionation on a column of Sephadex G-25 Fine.

\section{RESULTS}

\section{Amounts of macromolecular components in the luminal fuid}

The amounts of macromolecular material recovered from the saline washings of the uterine horns of cows in early pregnancy were small, 5 to $10 \mathrm{mg}$ being obtained per uterus during the first 2 to 3 weeks of pregnancy. The amounts increased to 15 to $25 \mathrm{mg}$ during the $3 \mathrm{rd}$ week of pregnancy. Secretion collected from a cannulated uterus of a cow also yielded only small amounts (5 to $10 \mathrm{mg}$ ) of macromolecular components in $24 \mathrm{hr}$ during oestrus (G. P. Roberts, J. M. Parker \& H. Symonds, unpublished observations).

\section{Polyacrylamide gel electrophoresis}

Both electrophoresis in tubes according to the method of Davis (1964) and electrophoresis on plates of polyacrylamide according to Akroyd (1967) have been carried out. For the purposes of the present investigation in which a number of samples were compared, the plate technique was found to be superior to the tubes. The saline washings and the $\mathrm{N}$-acetylcysteine washings of the uteri have been examined by electrophoresis but as the patterns obtained from both were very similar, the following account will refer only to the saline washings. For most of the electrophoretic separations, the washings from the two horns of the uterus from all 135 cows were pooled but in a few they were examined separately. The electrophoretic mobility of the proteins was expressed in terms of their mobility relative to the leading edge of the albumin band $(\mathrm{Ma} / \mathrm{b})$ when albumin is assigned an $\mathrm{Ma} / \mathrm{b}$ value of $1 \cdot 0$.

Conditions allowing migration to the anode, $p H$ 8.9. Although there were certain differences in the protein patterns of the uterine washings in the region between albumin and transferrin (the $\alpha_{1}$ and $\alpha_{2}$ region) when compared with fresh serum, these differences largely disappeared when they were compared with dialysed and freeze-dried serum since this gave a different pattern from that of untreated serum. The following gives more detail.

Albumin. All the samples showed an intense albumin band.

Postalbumin or $\alpha_{1}$. Most of the samples showed two usually rather faint bands, one of which was present in dialysed and freeze-dried serum. The other band appeared to be absent from freeze-dried serum but was similar to one of the bands in the $\alpha_{1}$ region of untreated serum.

Pretransferrin or $\alpha_{2}$. Most of the samples showed a broad band which was present in dialysed and freeze-dried serum but not in untreated serum. In some samples, this band was resolved into two or three narrow bands.

Transferrin. This was present in all samples and during the earlier stages of pregnancy ( 0 to 14 days) was comparable in amounts to that in dialysed and freeze-dried serum. 


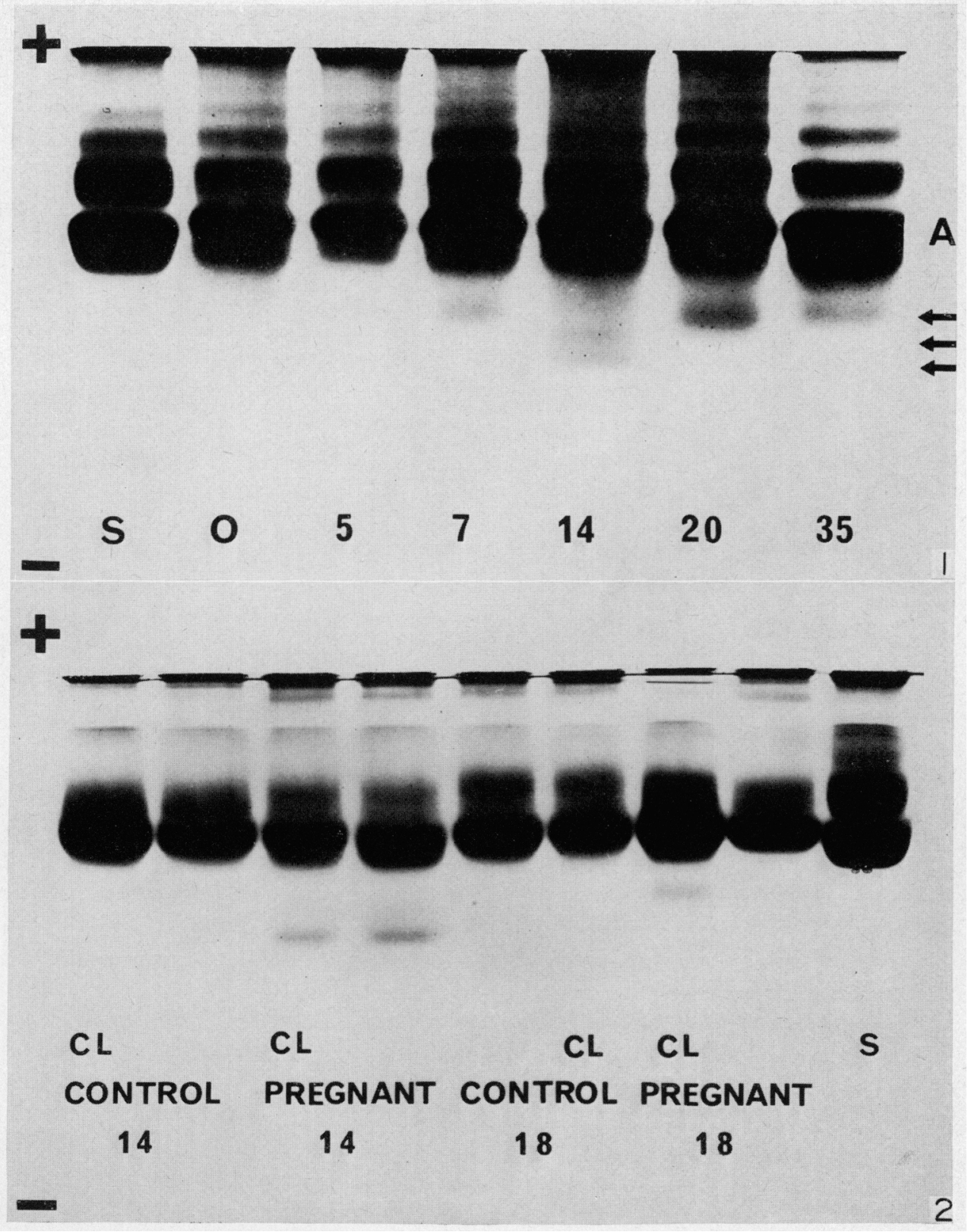

Fig. 1. Polyacrylamide gel electrophoresis at $\mathrm{pH} 4.5$ of bovine serum (S) and uterine washings from cows at oestrus (O) and at Days 5, 7, 14, 20 and 35 of pregnancy. The uterine-specific bands are indicated by the arrows and albumin by $\mathrm{A}$.

FIG. 2. Polyacrylamide gel electrophoresis at $\mathrm{pH} 4.5$ of bovine serum (S) and uterine washings from cows at Days 14 and 18 of pregnancy and of the oestrous cycle for which the day of oestrus is taken as Day 0 . The washings from the two horns were tested separately and the horn adjacent to the ovary containing the corpus luteum is indicated by CL.

(Facing p. 294) 
$\gamma$-Globulins. These were present in all samples but appeared to be fainter than in the serum samples. This was particularly evident in the samples from the later stages of pregnancy examined (14 to 35 days) in which the intensities of the bands of transferrin and $\gamma$-globulin relative to that of albumin were less than in serum.

Examination of the same series of samples for glycoproteins by staining with PAS revealed a pattern identical with that of the serum glycoproteins and no additional glycoproteins were detected.

Conditions allowing migration to the cathode, $p H 4 \cdot 5$. This proved to be a good system for revealing extra proteins which occur in the uterine washings but not in serum. In the washings from cows up to 35 days pregnant, additional rapidly migrating proteins were detected (Pl. 1, Fig. 1). In the uterine washings from a cow at oestrus and a 7-day pregnant cow, one of the proteins migrating to the cathode $(\mathrm{Ma} / \mathrm{b}=1 \cdot 20)$ was observed but, in the uterine washings from a 14-day pregnant cow, two other proteins $(\mathrm{Ma} / \mathrm{b}=1.3$ and 1.42$)$ were detected. These two had disappeared by 20 days of pregnancy and a slower migrating protein $(\mathrm{Ma} / \mathrm{b}=1 \cdot 20)$ was again observed. Although this migrated in a similar position to the bands observed in the samples from the oestrous and 7day pregnant cows, it was probably a different protein. Further electrophoretic separations have revealed that in most samples the transition from one slower migrating protein to two faster migrating proteins occurred at Day 12 and that the amounts of these increased to a maximum around Day 14 and then decreased subsequently until they were barely detectable by Day 18 . The amounts of the slower moving band $(\mathrm{Ma} / \mathrm{b}=1 \cdot 20)$ increased about Day 16 , reached maximum intensity by Day 18 and remained around this level in most of the samples examined up to 35 days of pregnancy. More recent work indicates that the bands migrating to the cathode described here may contain more than one molecular species but insufficient material has been examined to ascertain the relationships between these molecular species.

The amounts of the proteins migrating to the cathode were small; by comparison of the intensities of the bands with those obtained with known amounts of bovine serum albumin, they have been estimated to account for less than $2 \%$ of the total protein. The other proteins observed in this system migrate as serum proteins. Under these conditions at $\mathrm{pH} 4 \cdot 5$, lysozyme migrated with the marker dye $(\mathrm{Ma} / \mathrm{b}=1.90)$ and blastokinin also migrated rapidly $(\mathrm{Ma} / \mathrm{b}=1.62)$ whereas crystalline trypsin gave two bands $(\mathrm{Ma} / \mathrm{b}=1.20$ and 1.47$)$ which migrated in the region of the bands described above.

Comparison of the electrophoretic patterns of the individual uterine horns from five 14-day and six 18-day pregnant cows with the washings from the horns of unmated cows at Days 14 (four cows) and 18 (three cows) of the cycle revealed that although there was more of the two rapidly migrating proteins in both horns of the 14-day pregnant cows, these proteins were also present in both horns of the cows at Day 14 of the cycle (Pl. 1, Fig. 2). Very small amounts of these two proteins were also detected in both horns of 18-day unmated cows but in three of the 18-day pregnant cows, there was an interesting difference between the two horns. In the gravid horn, a slower moving band $(\mathrm{Ma} / \mathrm{b}=$ 1.20) was present in addition to very small amounts of the faster migrating 
proteins $(\mathrm{Ma} / \mathrm{b}=1.30$ and 1.42$)$; in the contralateral horn, this was missing and only traces of the two faster migrating bands were detected. This difference between the two horns of the 18-day pregnant cows was not always found and, in three animals, both horns contained the slower migrating band $(\mathrm{Ma} / \mathrm{b}=$ $1 \cdot 20)$.

Electrophoretic examination of the uterine washes from an ovariectomized cow which had been injected daily with $100 \mathrm{mg}$ progesterone for 2 months

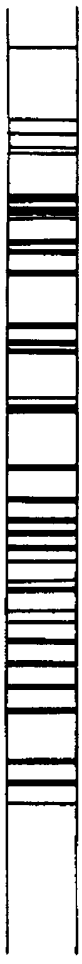

(a)

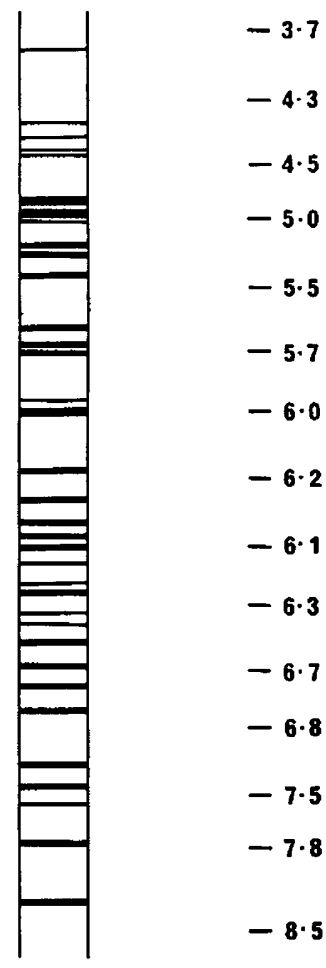

(b)
$\mathrm{pH}$

$-4 \cdot 3$

$-4.5$

$-5.0$

$-5.5$

$-5.7$

$-6.0$

$-6.2$

$-6.1$

$-6.3$

$-6 \cdot 7$

$-6.8$

$-7.5$

$-7.8$

$-8 \cdot 5$

TEXT-FIG. 1. Isoelectric focusing in polyacrylamide gel containing $\mathrm{pH} 3$ to 10 ampholytes of (a) bovine serum and (b) washings of the uterus from a 14-day pregnant cow.

before slaughter revealed three bands which migrated to the cathode $(\mathrm{Ma} / \mathrm{b}=$ $1.26,1.44$ and 1.59) in addition to serum proteins. Evaluation of the relationship of these proteins to the cathode-migrating proteins detected in the pregnant cows must await the development of antisera to these proteins but it is perhaps not too surprising that these appear to be different proteins since the progesterone treatment was carried out for a period longer than any length of pregnancy we examined.

\section{Isoelectric focusing in polyacrylamide gels}

Gel isoelectric focusing of the saline washes of the uterine horns from cows at 0 to 35 days of pregnancy were compared with serum. Up to thirty-five bands 
(a)
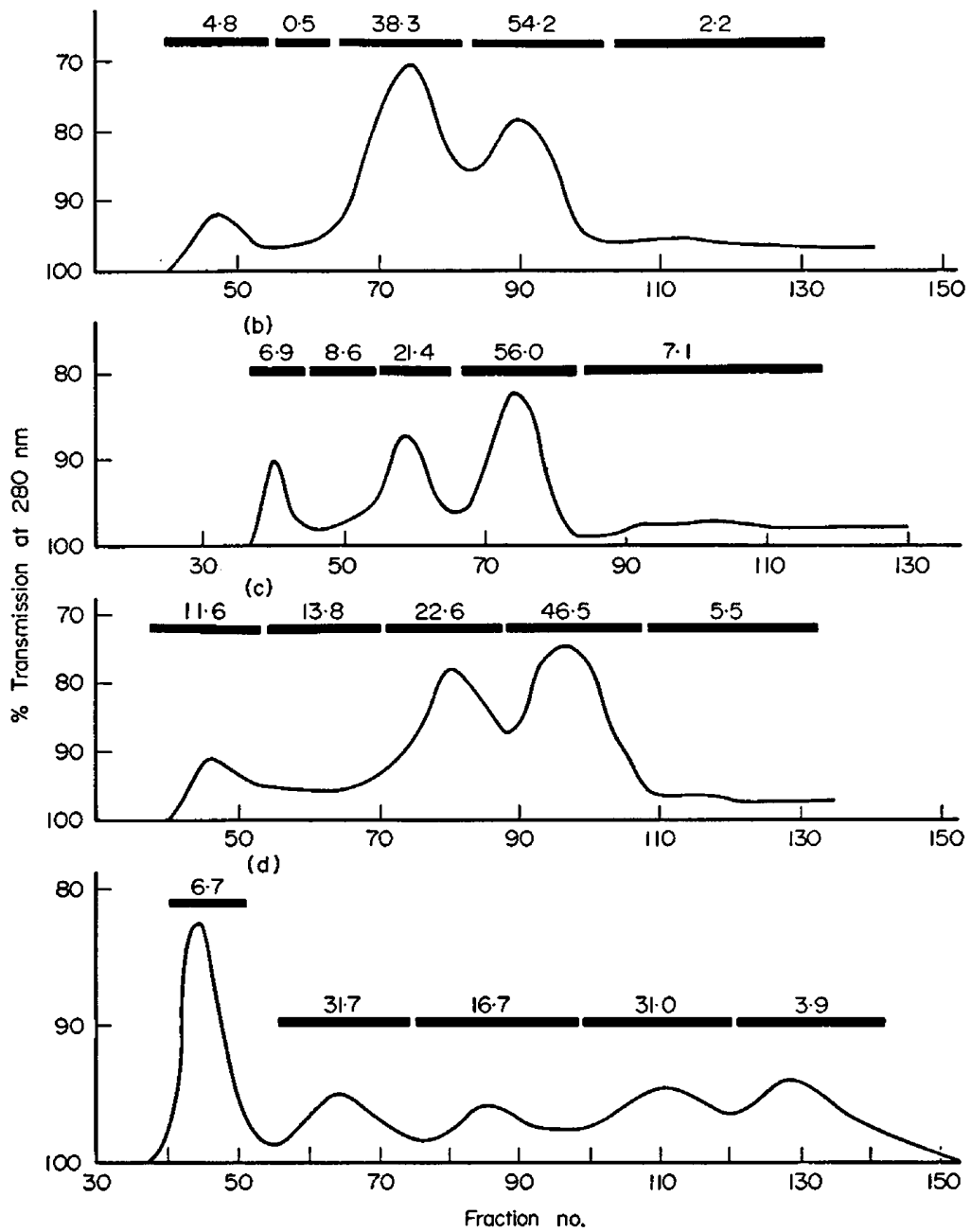

TEXT-FIG. 2. Diagrams of protein distribution in eluates from Sephadex G-200 gel filtration at $\mathrm{pH} 7.4$ of (a) bovine serum, (b) N-acetylcysteine washings of the uterus from a cow at oestrus, (c) saline washings of the uterus from a 21-day pregnant cow, and (d) saline washings of the uterus from a 5-day pregnant rabbit. A column of $1.5 \mathrm{~cm} \times 88 \mathrm{~cm}$ was used for (a) (c) and (d), and a column of $1.5 \mathrm{~cm} \times 80 \mathrm{~cm}$ was used for (b). Fractions were combined as indicated by the solid bars and the amount of material recovered in each fraction has been expressed as a percentage of the total by the numbers above the solid bars.

were detected in the uterine washings but all except the two most basic bands (isoelectric points in the range $\mathrm{pH} 7.5$ to 8.5 ) were present in serum as well (Text-fig. 1).

\section{Gel filtration}

(a) The elution diagrams off Sephadex G-200 at $\mathrm{pH} 7 \cdot 4$ of uterine washings from a cow at oestrus and one at 21 days of pregnancy are compared with bovine serum and the uterine washings from a 5-day pregnant rabbit in Text-fig. 2. 
There was a marked similarity between the bovine uterine washings and bovine serum although there were indications that the uterine secretions contained rather more of the excluded fraction. This fraction and also the two more slowly migrating peaks were combined as shown and the fractions were examined by disc electrophoresis at $\mathrm{pH} 8 \cdot 9$. No differences were observed in the electrophoretic patterns of the fraction from the bovine uterine washings and those from bovine serum.

By contrast, a completely different elution diagram was obtained with the uterine washes from a 5-day pregnant rabbit, considerably more of the lower molecular weight fractions being obtained. Blastokinin occurred in the combined Fraction 4 in (d) of Text-fig. 2 and although the absorption of this peak at $280 \mathrm{~nm}$ was not very great, this was one of the major fractions isolated after dialysis and freeze drying and contained $31 \%$ of the total material. However, combination of similar fractions from the bovine uterine washings followed by freeze drying did not yield any blastokinin-like protein.

(b) Exploratory experiments using DEAE-Sephadex suggested that the uterine-specific proteins were absorbed to other proteins at neutral $\mathrm{pH}$ and, consequently, gel filtration at an acidic $\mathrm{pH}$ below the isoelectric point of albumin was carried out. The saline washings from the uterus of a 15-day pregnant cow was fractionated on a column $(0.6 \mathrm{~cm} \times 50 \mathrm{~cm})$ of Sephadex G-100 using 0.1 m-pyridine acetate $\mathrm{pH} 4.0$ for elution. Each fraction was freeze dried and then examined by disc electrophoresis at $\mathrm{pH} 4.5$ and 8.9 and by isoelectric focusing on polyacrylamide gel. The cathode-migrating proteins observed at $\mathrm{pH} 4.5$ were detected in the eluates containing the descending region of the albumin peak and corresponded with a relatively intense and diffuse band in the $\gamma$-region $(\mathrm{Ma} / \mathrm{b}=0.16)$ and two fainter bands $(\mathrm{Ma} / \mathrm{b}=0.55$ and 0.83 ) in the $\beta$ - and $\alpha$-regions on disc electrophoresis at $\mathrm{pH} \mathrm{8.9.} \mathrm{On} \mathrm{iso-}$ electric focusing in polyacrylamide gel, these bands corresponded with two proteins of isoelectric points in the range $\mathrm{pH} 8.4$ to 8.6 and one protein with isoelectric point in the range $\mathrm{pH} 5.0$ to 5.5 . Calibration of the column with proteins of known molecular weight indicated that the molecular weights of these proteins were in the range 15,000 to 35,000 . An accurate assessment of molecular weight was difficult under these conditions due to the small size of the column and the difficulty in assessing exactly which fraction contained the maximum amounts of these uterine-specific proteins.

\section{Immunological examination of the uterine proteins}

On immunoelectrophoresis using the method of Scheidegger (1955), the antiserum to bovine serum gave up to fourteen precipitin lines with fresh serum and with dialysed and freeze-dried serum but the positions of some of the lines differed. The differences between the two serum samples were most evident in the region of the $\alpha$ - and $\beta$-globulins. A commercial sample of antibovine serum prepared in rabbit (Paines \& Byrne Ltd, Greenford, Middlesex) produced a similar pattern of precipitin lines to our antiserum. Immunoelectrophoretic examination of the saline washes from uteri of 13-day or 21-day pregnant cows using the antiserum directed against bovine serum yielded up to ten precipitin lines, the patterns being similar to those obtained with dialysed 
and freeze-dried serum except that some of the faint lines in the $\beta$ - and $\gamma$ regions were absent.

Examination of the uterine washings from cows at oestrus or from 7-, 14- or 21-day pregnant cows by crossed immunoelectrophoresis using antiserum directed against bovine serum in all cases gave patterns with an overall similarity to those obtained with dialysed and freeze-dried serum. The areas enclosed by some of the arcs in the $\alpha$ - and $\beta$-region were smaller, relative to that of albumin, in the uterine washings than in serum. Some of the arcs which occurred in this region in serum were missing from the patterns obtained with the uterine washings, a total of thirteen arcs being detected in the latter compared with seventeen in the former.

The antisera raised in rabbits against bovine uterine washings yielded on immunoelectrophoretic examination a pattern of precipitin lines against dialysed and freeze-dried serum which was largely similar to that obtained using antiserum to bovine serum, the most intense precipitin lines being common to both patterns. There was some difference in the fainter precipitin lines, a number of which were missing in the $\beta$ - and $\gamma$-region when the antisera to bovine uterine washings were used, which yielded only seven precipitin lines. Examination of the uterine washings of 13-day or 21-day pregnant cows by immunoelectrophoresis using the anti-uterine washing yielded a pattern of precipitin lines that was virtually identical to those obtained with dialysed and freeze-dried serum against this antiserum.

When the antiserum prepared against uterine washings was adsorbed with dialysed and freeze-dried bovine serum, the resulting antiserum gave no precipitin line on immunoelectrophoresis of some samples of uterine washings and only very faint precipitin lines in the $\beta$ - and $\gamma$-region with other samples. There did not appear to be any correlation in the appearance of these faint lines with the stage of pregnancy or with the intensity of the cathode-migrating proteins detected by disc electrophoresis at $\mathrm{pH} 4.5$. One sample from one oestrous cow before ovulation gave seven very faint precipitin lines whereas that from another cow which was at oestrus and had just ovulated gave no lines. Further samples of uterine washings from pregnant cows at 7 days, 13 days, 21 days, 28 days and 41 days yielded no lines whereas an 11-day pregnant cow gave one line and 14-, 16- and 18-day pregnant cows gave three lines which were not identical. The reason for this variation in the uterine washings is not known with certainty but it may be related to genetic differences in the cows examined.

\section{Examination of the uterine fuid for the presence of an epithelial glycoprotein}

Electrophoretic examination of the soluble part of the saline and $\mathrm{N}$-acetylcysteine washes of the uteri failed to reveal the presence of a glycoprotein which was not present in serum. Whereas gel filtration did suggest the presence of a slightly hexose-enriched high molecular weight component, this was present in only very small amounts. Consequently, the precipitates from the $\mathrm{N}$-acetylcysteine washing, which sometimes had a slightly mucus-like appearance, and the scrapings of the uterine wall were examined in an attempt to isolate an epithelial glycoprotein. 
(a) The $\mathrm{N}$-acetylcysteine precipitate was treated with $0 \cdot 1 \mathrm{M}$-dithiothreitol followed by extraction with $6 \mathrm{~m}$-urea and precipitation of the supernatant with 3 vols of ethanol. No significant amounts of glycoprotein were isolated by this procedure.

(b) The uterine scrapings were treated with Pronase, then the digest was dialysed against distilled water and freeze dried. The material recovered (9 $\mathrm{mg}$ from a complete uterus) contained large amounts of deoxyribonucleic acid but only small amounts of glycoprotein, the hexosamine and sialic acid accounting for only $3.9 \%$ and $2.7 \%$, respectively, of the dry weight.

(c) The uterine scrapings were digested with Pronase and the digest was fractionated on a column $(1.8 \mathrm{~cm} \times 88 \mathrm{~cm})$ of Sephadex G-25 fine using 0.02 Mphosphate/0.01 м-citrate buffer, $\mathrm{pH} 6 \cdot 4$. The eluate was monitored for protein at $280 \mathrm{~nm}$ and for hexose by the anthrone reaction. Only trace amounts of hexose were detected in the excluded fraction.

In a small number of the uteri examined in the present investigation, some mucus-like material was observed in the uterus but since the number of cows in which this was observed was small (less than $4 \%$ of animals examined) and did not appear to be related to the stage of pregnancy, it is assumed that this was due to contamination by cervical mucus possibly during slaughter and removal of the genital tract from the carcase. When mucus was observed in the uterus, there were copious amounts of cervical mucus in the cervix and anterior end of the vagina.

\section{DISCUSSION}

The results presented above emphasize the similarity of the macromolecules in the luminal fluid of the bovine uterus to those present in serum. There are uterine-specific proteins present in the fluid but these are minor components. This was rather surprising in view of findings in the rabbit (Krishnan \& Daniel, 1967; Beier, 1968; Kirchner, 1969a, b) in which blastokinin (or uteroglobulin) accounted for up to $50 \%$ of the proteins in the uterine fluid during early pregnancy. It appears, however, that the rabbit is unique in this respect and although blastokinin-like materials have been reported in other species (e.g. mink: Daniel, 1968; pig and dog: Daniel \& Krishnan, 1969; northern fur seal: Daniel, 1972; man: Shirai et al., 1972), they are present in low concentrations and have not been well characterized.

Since blastulation occurs at about Day 8 in the cow, it is at this time that one might expect to find a protein analogous to blastokinin which has been reported to influence blastocyst formation in the rabbit (Krishnan \& Daniel, 1967; El-Banna \& Daniel, 1972). Although the cathode-migrating protein ( $\mathrm{Ma} / \mathrm{b}=$ $1 \cdot 20$ ) detected by disc electrophoresis at $\mathrm{pH} 4.5$ in cows up to 11 days of pregnancy is present in much smaller amounts and does not appear to show the marked variation in amounts with length of pregnancy shown by blastokinin, its isolation and characterization is desirable so that its effect on early embryonic development using in-vitro techniques can be evaluated. The appearance of two faster cathode-migrating proteins $(\mathrm{Ma} / \mathrm{b}=1.30$ and 1.42$)$ on Day 12 is interesting since it is about Day 13 or 14 that a very rapid elongation of the blastocyst 
occurs in the cow and it is tempting to speculate that these proteins may influence the embryonic development at this stage. These proteins cannot be embryonic products since they also occur in unmated cows at this stage of the cycle and since this is close to the time of maximum progesterone production, it is likely that their secretion is progesterone-dependent. Little is known of the influence that uterine fluids can have on blastocyst development at this stage but it is of interest that uterine-specific proteins have recently been detected in the pig (Murray, Bazer, Wallace \& Warnick, 1972; Squire, Bazer \& Murray, 1972) at a similar stage of blastocyst development and that at least one of these is a cathode-migrating protein on disc electrophoresis. In the pig, the appearance of these uterine-specific proteins has been shown to be progesteronedependent (Knight, Bazer \& Wallace, 1973).

The slower cathode-migrating protein $(\mathrm{Ma} / \mathrm{b}=1 \cdot 20)$ detected between 16 and 35 days of pregnancy is probably an embryonic product or produced as a result of the influence of the embryo on the endometrium since in some cows in the early stages of this period it was detected in the gravid horn but not in the contralateral horn. In the unmated cow, the progesterone concentration in the peripheral blood system falls most rapidly around Day 18 of the oestrous cycle and although the conceptus has no influence on plasma progesterone levels before Day 14 after insemination, the influence is very marked by Day 18, greatly increased levels of progesterone being observed at this stage (Pope, Gupta \& Munro, 1969). This suggests that the conceptus counteracts the luteolytic effect of prostaglandin $\mathrm{F}_{2 \alpha}$ produced in the endometrium towards the end of the cycle. This compound is believed to be the main luteolytic agent in ruminants (McCracken \& co-authors, 1972). By using embryo transfer experiments in sheep, Rowson \& Moor (1967) have shown that a heat-labile factor in the embryonic membranes is implicated in the process of prolonging the life of the corpus luteum and that this factor must be present in the uterus of a recipient sheep by Day 13 for pregnancy to be maintained (Moor \& Rowson, 1966). The cathode-migrating protein $(\mathrm{Ma} / \mathrm{b}=1 \cdot 20)$ detected in the gravid horn of the cow at about Day 16 may be involved in this luteolytic mechanism and some preliminary experiments with sheep add some support to this, a cathode-migrating protein also being detected in the uterine washings of pregnant sheep after Day 13 but not before.

Investigations designed to evaluate the possible significance of these cathodemigrating proteins on embryonic development and control of luteolysis suggested above are now in progress. It is hoped that these studies may help to elucidate the basis of the synchronization requirements for successful egg transfer in the cow (Rowson, Lawson, Moor \& Baker, 1972) and define the stages of early embryonic development which are particularly susceptible to the components of their environment.

\section{ACKNOWLEDGMENTS}

This work was supported by a grant from the Population Council, Rockefeller University, New York, to whom we express our grateful thanks.

We are indebted to Mrs M. Hoare and Dr H. Symonds for ovariectomy 
and cannulating the uteri of cows and to Mr I. Jebbett for photography of the electrophoretic gels. Finally, we wish to thank Dr R. A. Gibbons and Dr J. M. Payne for their encouragement and advice throughout this research and in the preparation of the manuscript.

\section{REFERENCES}

Akroyd, P. (1967) Acrylamide gel slab electrophoresis in a simple glass cell for improved resolution and comparison of serum proteins. Analyt. Biochem. 19, 399.

Awdeh, Z. L., Williamson, A. R. \& Askonas, B. A. (1968) Isoelectric focusing in polyacrylamide gel and its application to immunoglobulins. Nature, Lond. 219, 66.

BEIER, H. M. (1968) Uteroglobulin: a hormone-sensitive endometrial protein involved in blastocyst development. Biochim. biophys. Acta, 160, 289.

Bernstein, G. S., Aladjem, F. \& Ghen, S. (1971) Proteins in human endometrial washings-a preliminary report. Fert. Steril. 22, 722.

DANiEL, J. C. (1968) Comparison of electrophoretic patterns of uterine fluid from rabbits and mammals having delayed implantation. Comp. Biochem. Physiol. 24, 297.

Daniel, J. G. (1971) Uterine proteins and embryonic development. Adv. Biosci. 6, 191.

DANIEL, J. C. (1972) Blastokinin in the northern fur seal. Fert. Steril. 23, 78.

Daniel, J. C. \& KRISHNAN, R. S. (1969) Studies on the relationship between uterine fluid components and the diapause state of blastocysts from mammals having delayed implantation. F. exp. Zool. $172,267$.

Davies, D. R., Spurr, E. D. \& Versey, J. B. (1971) Modification to the technique of two-dimensional immunoelectrophoresis. Clin. Sci. 40, 411.

Davis, B. J. (1964) Disc electrophoresis. II. Method and application to human serum proteins. Ann. N.Y. Acad. Sci. 121, 404.

El-BanNa, A. A. \& Daniel, J. G. (1972) The effect of protein fractions from rabbit uterine fluids on embryo growth and uptake of nucleic acid and protein precursors. Fert. Steril. 23, 105.

IrITANI, A., Gomes, W. R. \& VanDemark, N. L. (1969) Secretion rates and chemical composition of oviduct and uterine fluids in ewes. Biol. Reprod. $1,72$.

KIRCHNER, G. (1969a) Untersuchungen on uterusspezifischen Glykoproteinen während den Frühen gravidität des Kaninchens (Oryctolagus cuniculus). Willhelm Roux Arch. Entw Mech. Org. 164, 97.

KIRCHNER, C. (1969b) Glykoproteine im Uterussekret des Kaninchens während der Frühen Entwicklung der Blastozyste. Zool. Anz., Suppl. 33, 133.

KNIGHT, J. W., BAZER, F. W. \& WALLACE, H. D. (1973) Hormonal regulation of porcine uterine protein secretion. F. Anim. Sci. 36, 546.

Krishnan, R. S. \& Daniel, J. G. (1967) "Blastokinin": inducer and regulator of blastocyst development in the rabbit uterus. Science, N.Y. 158, 490.

Krishnan, R. S. \& Daniel, J. C. (1968) Composition of "blastokinin" from rabbit uterus. Biochim. biophys. Acta, 168, 579.

McGracken, J. A., Garlson, J. G., Glen, M. E., Goding, J. R., Baird, D. T., Green, K. \& Samuelson, B. (1972) Prostaglandin $F_{2 \alpha}$ identified as a luteolytic hormone in sheep. Nature, New Biology, 238, 129.

McGaughey, R. W. \& Murray, F. W. (1972) Properties of blastokinin; amino acid composition evidence for subunits and estimation of isoelectric point. Fert. Steril. 23, 399.

Moor, R. M. \& Rowson, L. E. A. (1966) The corpus luteum of the sheep: functional relationship between the embryo and the corpus luteum. F. Endocr. 34, 233.

Murray, F. A., Bazer, F. W., Wallace, H. D. \& Warnick, A. G. (1972) Quantitative and qualitative variation in the secretion of protein by the porcine uterus during the oestrous cycle. Biol. Reprod. 7,314 .

Murray, F. A., McGaughey, R. W. \& Yarus, M. J. (1972) Blastokinin: its size and shape, and an indication of the existence of subunits. Fert. Steril. 23, 69.

Olds, D. \& VanDemark, N. L. (1957) Composition of luminal fluids in bovine female genitalia. Fert. Steril. 8, 345.

Ouchterlony, O. (1958) Diffusion-in-gel methods for immunological analysis. Progr. Allergy, 5, 1.

Pope, G. S., Gupta, S. K. \& Munro, I. B. (1969) Progesterone levels in the systemic plasma of pregnant, cycling and ovariectomized cows. F. Reprod. Fert. 20, 369.

Reisfeld, R. A., Lewis, U. J. \& Williams, D. E. (1962) Disc electrophoresis of basic proteins and peptides on polyacrylamide gels. Nature, Lond. 195, 281.

Rowson, L. E. A., Lawson, R. A. S., Moor, R. M. \& BAKER, A. A. (1972) Egg transfer in the cow: synchronization requirements. F. Reprod. Fert. $28,427$. 
Rowson, L. E. A. \& Moor, R. M. (1967) The influence of embryonic tissue homogenate infused into the uterus on the life-span of the corpus luteum in the sheep. F. Reprod. Fert. 13, 511.

Scheidegger, J. J. (1965) Une micro-méthode de l'immune électrophorèse. Int. Archs Allergy appl. Immun. 7, 103.

ScHwick, H. G. (1965) Chemische-entwicklungsphysiologische Beziehungen von Uterus zu Blastocyste des Kaninchens (Oryctolagus cuniculus). Willhelm Roux Arch. EntwMech. Org. 156, 283.

Shirai, E., IIzuka, R. \& Notake, Y. (1972) Analysis of human uterine fluid protein. Fert. Steril. 23, 522.

SQuire, G. D., BAzer, F. W. \& MURray, F. A. (1972) Electrophoretic patterns of porcine uterine protein secretions during the estrous cycle. Biol. Reprod. 7, 321.

VeSTERBERG, O. (1971) Staining of protein zones after isoelectric focusing in polyacrylamide gels. Biochim. biophys. Acta, 243, 345.

Zacharius, R. M., Zell, T. E., Morrison, J. H. \& Woodlock, J. J. (1969) Glycoprotein staining following electrophoresis on acrylamide gels. Analyt. Biochem. 30, 148. 